\title{
A Tale of Oversimplification and Deregulation: The Mainstream Approach to Labour Market Segmentation and Recent Responses to the Crisis in European Countries
}

\author{
VALERIO DE STEFANO*
}

\section{ABSTRACT}

After advocating flexibilisation of non-standard work contracts for many years, some European and international institutions and several policy makers now indicate the standard employment relationship and its regulation as a cause of segmentation between the labour market of 'protected' insiders, employed under permanent contracts with effective protection against unfair dismissal, and the market of the 'non-protected' outsiders, working with non-standard contracts. Reforms of employment legislation are therefore being promoted and approved in different countries, supposedly aiming to balance the legal protection afforded to standard and nonstandard workers. This article firstly argues that this approach is flawed as it oversimplifies reasons for segmentation and concentrates on an 'insider-outsider' discourse that cannot easily be transplanted into continental Europe. After reviewing current legislative changes in Italy, Spain and Portugal, I argue that lawmakers have focused on 'deregulation' rather than 'balancing protection' when approving recent reforms. I question the mainstream approach to segmentation and some of its derivative proposals, such as calls to introduce a 'single permanent contract', on the grounds that they neglect the essential role of job protection in underpinning the effectiveness of fundamental and constitutional rights at the workplace.

\footnotetext{
* Postdoctoral Researcher with Grant, Università Commerciale 'Luigi Bocconi', Milano; Postdoctoral member, Clare Hall College, University of Cambridge, email: valerio.destefano@ unibocconi.it. I owe special thanks to the Editor, Professor Simon Deakin, to the anonymous referees and to Francesco Corsello, Maurizio Del Conte, Ewan McGaughey, Orsola Razzolini and Bart Ullstein for their precious feedbacks. I benefited greatly from discussions with Nicola Countouris (during my period as a visiting academic at UCL, in 2012, and afterwards), Stefano Liebman and Silvana Sciarra and with the participants and organizers of the ILO Research Workshop, Employment Quality in Segmented Labour Markets, Geneva, 2013. Finally, this article was mainly written during my postdoctoral membership at Clare Hall College, University of Cambridge, in 2013: I wish to thank deeply Clare Hall and its president, Professor David Ibbetson for their hospitality. The usual disclaimer applies.
} 


\section{INTRODUCTION}

During the last 30 years, there has been a distinct growth of labour market policies professedly aimed at promoting the creation of employment ${ }^{1}$ through the use of non-standard work contracts, ${ }^{2}$ such as fixed-term and/ or part-time employment or temporary agency work (TAW). In most of the cases, these reforms neither significantly affected the open-ended, full-time standard contract of employment nor the relevant dismissal regulations.

This 'flexibility at the margin' approach has now been called into question even by those institutions that had previously advocated deregulation of non-standard and 'flexible' forms of employment:" the risk, it is now argued, is that workers, particularly young workers, or women or workers belonging to disadvantaged groups are 'trapped' in an endless series of precarious, instable working contracts for a considerable amount of their working lives. It is suggested, in particular, that facilitating the use of temporary work contracts, without reforming the open-ended employment relationship by loosening protections against dismissal, has been the cause of a damaging segmentation of the labour market. Additionally, strong dismissal protection, it is argued, incentivises employers to look for contractual arrangements granting the elimination or the reduction of termination costs. This process, it is suggested, generates 'dualism' of labour markets, namely a sharp division between the labour market of insiders, 'protected' workers

\footnotetext{
${ }^{1}$ There is no consensus on the potentialities of using temporary work contracts as 'stepping stones' towards stable jobs. See A.L. Booth, M. Francesconi and J. Frank, 'Temporary Jobs: Stepping Stones or Dead Ends?' (2002) 112 Economic Journal 189-213; G. Barbieri and P. Sestito, 'Temporary workers in Italy: Who Are They and Where They End Up?' (2008) 22 Labour 127-166; F. Berton, F. Deficienti and L. Pacelli, 'Are Temporary Jobs a Port of Entry into Permanent Employment? Evidence from Matched Employer-Employee Data' (2009) 6 Department of Economics and Public Finance 'G.Prato' Working Paper Series (accessed 14 December 2013).

${ }^{2}$ For a comparative overview of fixed-term work regulation in France, Germany, Italy. Spain and the UK, see B. Caruso and S. Sciarra (eds.), 'Flexibility and Security in Temporary Work: A Comparative and European Debate' WP CSDLE 'Massimo D'Antona' INT-56/2007.

${ }^{3}$ For instance, Directive 2008/104/EC and Directive 1999/70/EC indicate non-standard forms of employment as an effective way to, respectively 'contribute to job creation' and to 'respond, in certain circumstances, to the needs of both employers and workers'. See also, The OECD Jobs Study. Facts, Analysis, Strategies, 1994. On this point, see N. Countouris and M. Freedland, 'Labour regulation and the economic crisis in Europe: challenges, responses and prospects', in J. Hayes, L. Rychly (eds.), Labour Administration in Uncertain Times. Policies, Practices and Institutions (Cheltenham: Edward Elgar 2013).
} 
with permanent contracts and protection against termination of employment, and the market of outsiders, the 'non-protected', forced into a prolonged and indefinite series of non-standard contracts characterised by high instability. ${ }^{4}$

Segmentation of the labour market as a direct result of the regulation governing dismissal is an issue currently under discussion at the economic, legal and political institutions in different European countries. According to the EU Commission, for instance, in order to tackle the issue of segmentation, 'employment protection legislation should be reformed to reduce overprotection of workers with permanent contracts, and provide protection to those left outside or at the margins of the job market'.5 Accordingly, several reforms have been proposed or enacted across EU Member States in recent years to address these issues.

In a recent paper, Simon Deakin provided an extensive overview of economic and legal theories of labour market segmentation. ${ }^{6} \mathrm{He}$ identified three types of institutional responses to segmentation, followed by several European countries in recent years:

(i) A first technique implies changes in the scope of labour law protections, including 'legal measures that widen the definition of wage-dependent labour and minimise or remove qualifying thresholds' in order to have 'fewer workers $[. .$.$] excluded from the "core" protected category';$

(ii) The second type of responses concerns 'the content of labour law protections', for instance, by 'mandating equal (or pro rata) protections for workers in atypical work relationships to those in the "core" ("levelling up")' and/or 'reducing the protections which apply to the workers in the core, so as to bring them closer into line with those in the atypical categories ("levelling down")';

${ }^{4}$ See O. Blanchard and A. Landier, 'The Perverse Effects of Partial Labor Market Reform: Fixed Duration Contracts in France' (2012) 112 Economic Journal 214-244; T. Boeri and P. Garibaldi, 'Two Tier Reforms of Employment Protection: a Honeymoon Effect?' (2007) 117 Economic Journal 357-385; S. Bentolila, J. F., Jimeno and J. J. Dolado 'Reforming an InsiderOutsider Labor Market:The Spanish Experience' (2012) 01 Working Papers FEDEA (accessed 9 April 2014); R. Bouis, O. Causa, L. Demmou, R. Duval and A. Zdzienicka, 'The ShortTerm Effects of Structural Reforms: An Empirical Analysis?, (2012) 949 OECD Economic Department Working Papers (Paris: OECD).

${ }^{5}$ EU Commission, 'Communication from the Commission to the European Parliament, the European Economic and Social Committee and the Committee of Regions, Annual Growth Survey: Advancing the EU's Comprehensive Response to the Crisis' COM (2011) 11 final. A similar approach is followed by OECD, Economic Policy Reforms 2012: Going for Growth, OECD Publishing.

${ }^{6}$ S. Deakin, 'Addressing Labour Market Segmentation: The Role of Labour Law' (2013) Working Paper No. 52, Governance and Tripartism Department (Geneva: International Labour Office). 
(iii) Techniques which use the law 'to stimulate alternative mechanisms of labour market regulation' such as 'collective bargaining, training policy and fiscal incentives'

Grouping legal responses into these three categories is helpful in assessing the scope of recent labour market regulation reforms across Europe. These categories, however, do not necessarily have rigid confines: it will be argued below that they may have rather 'fluid' or 'flexible' borders, with some legal responses falling simultaneously within, or sometimes at the border between, two categories.

Additionally, in the last decade, the EU Commission constantly called for 'addressing segmented labour markets, through reforms in line with the "flexicurity" approach that shift the focus from protection on the job to employment security in the market? ${ }^{7}$

This article deals with the mainstream approach to addressing segmentation of the labour market and with the reforms adopted or proposed in different countries, supposedly aimed at boosting employment rates affected by the current economic crisis, ${ }^{8}$ that are purportedly consistent with this approach. It will be argued that the mainstream narrative of segmentation, which presents this issue as a matter of two-tier labour markets divided on the basis of the regulation of standard employment relationship, draws on a very limited set of theories concerning segmentation, namely 'insider-outsider' theories which have been merged with certain legal theories concerning segmentation. The insights of alternative economic and legal theories on this issue have been disregarded by the mainstream approach: this results in an oversimplification of the issues, and to neglect of the reality of European labour markets.

${ }^{7} \mathrm{EU}$ Commission 'Commission Working Document, European Commission Background Paper to the EPSCO Council, The Employment crisis. Trends, Policy Responses and Key Actions', 2009. See also, EU Commission, 'Modernising labour law to meet the challenges of the 21st century' 22.11.2006 COM(2006) 708 final GREEN PAPER.

${ }^{8} \mathrm{~A}$ vast literature already exists on the ideas underpinning labour market policies undertaken by European countries and/or supported by European and international institutions: see C. Barnard, 'The Financial Crisis and the Europlus Pact: a Labour Lawyer's Perspective' (2012) 41 Industrial Law Journal 98-114; S. Sciarra, 'Common Places, New Places. The Labour Law Rhetoric of the Crisis', WP CSDLE 'Massimo D’Antona' INT 92/2012; A. Koukiadaki and L. Kretsos, 'Opening Pandora's Box: The Sovereign Debt Crisis and Labour Market Regulation in Greece' (2012) 41 Industrial Law Journal 276-304; S. Dahan, 'The EU/IMF Financial Stabilisation Process in Latvia and Its Implications for Labour Law and Social Policy' (2012) 41 Industrial Law Journal 305-327; S. Deakin and A. Koukiadaki, 'The Sovereign Debt Crisis and the Evolution of Labour Law in Europe' in N. Countouris and M. Freedland (eds.), Resocialising Europe in a Time of Crisis (Cambridge: Cambridge University Press 2013); N. Countouris and M. Freedland (n.3). 
As for the 'flexicurity' approach, it has first of all been argued that, if one looks at the convergence in labour policies across Europe, 'there has not been a general tendency towards the adoption of labour market policies designed to deliver "flexicurity": the dominant trend has instead been towards less security. ${ }^{9}$ Leaving aside the fact that EU Member States may not all have responded to the call for flexicurity, this article will argue that urging a shift from job-based protection to 'employment security in the market' may lead to the neglect of some important features of the employment relationship, the role of job protection and, in general, of employment regulation.

Section 2 will deal with the main ideas underpinning the mainstream approach to segmentation of the labour market and refers to an alternative theoretical explanation of this phenomenon. Section 3 questions the very idea of 'dual' labour markets, pointing out that working conditions may vary considerably among supposed 'insiders' on the basis of various elements unrelated to the scope of unfair dismissal regulations or to other legal features. Section 4 outlines some findings of the 'insider-outsider' economic theories, showing that they do not significantly deal with the legal regulation of unfair dismissal but chiefly focus instead on traditional aspects of the US industrial relations system. Section 5 outlines the reforms recently passed in some EU Member States as a response to the crisis and shows how, when shaping these reforms, lawmakers decided to follow a distinct deregulatory path rather than reduce the gap between the protections of standard and non-standard workers. This section firstly highlights how protection against unfair dismissal was materially loosened under the recent reforms. Secondly, it shows that no significant increase in the protection of the non-standard workers has occurred: in some jurisdictions, this protection was instead reduced. It then argues that recent reforms endorsed by the EU Commission and aimed at the decentralisation of collective bargaining systems in different countries may weaken the 'inclusive' nature of industrial relations systems of continental Europe, potentially leading to the marginalisation of non-standard workers. Section 6 underlines that

${ }^{9}$ J. Heyes, 'Flexicurity, Employment Protection and the Jobs Crisis' (2011) 25 Work Employment Society 642-657. See also S. Sciarra, 'Is Flexicurity a European Policy?' (2008) 4 URGE Working Paper (accessed 9 April 2014); M. Del Conte, 'L'influenza del diritto comunitario sul diritto del lavoro italiano fra tutele e flessibilità', in M. Napoli, M. Magnani (eds.), Studi Treu, Lavoro, Istituzioni, cambiamento sociale (Napoli: Jovene 2011); L. Zappalà, 'Flexicurity e valorizzazione delle capability: l'impulso alla ri-regolamentazione del lavoro a termine' WP CSDLE 'Massimo D'Antona'. INT-97/2012; S. Deakin (n.6). 
segmentation of the labour market is not a novel phenomenon originating in recent 'flexibility-at-the-margin' reforms, but has been a permanent feature of capitalist labour market since the dawn of industrialisation and might have sharpened as a result of entrepreneurial trends towards business de-concentration in the last 40 years, augmenting the divide between core and marginal workforces. Section 7, then, argues that proposed reforms aimed at introducing the 'single permanent contract' and, in general, policies aimed at reducing dualism between standard and non-standard workers by flattening the relevant legal protections may prove unsatisfactory, as they neglect the differences between marginal and core business activities and workforce. Section 8 remarks on the role of job protection and dismissal regulation not only in preserving the employee's income but also in supporting the effectiveness of fundamental and constitutional rights during the course of the employment. Section 9 concludes.

\section{THE MAINSTREAM APPROACHTO SEGMENTATION: A TALE OF OVERSIMPLIFICATION}

As already mentioned, European institutions tend to follow, implicitly or explicitly, a particular explanation for segmentation of labour markets: segmentation is, more often than not, referred to a matter of 'dualism' concerning an allegedly 'two-tier' labour market where 'insiders' benefit 'from high levels of employment protection' while 'outsiders' are 'recruited under alternative forms of contracts with lower protections. ${ }^{10}$ In this respect, the Kok Report, for example, argued that 'overly protective terms and conditions can deter employers from hiring in economic upturns or encourage them to resort to other forms of contract, which can have a negative impact on the ability of less advantaged workers - notably young people, women and the long-term unemployed - to access jobs' In order to address these issues, the report particularly advocated 'where necessary', altering 'the level of flexibility provided in standard contracts in areas such as periods of notice, costs and procedures for individual and collective dismissal, or the definition of unfair dismissal' and 'in parallel' reviewing 'the role of other forms of contract $[\ldots]$ with a view to providing more options for employers and employees depending on their needs and adequate security for workers'. The EU Commission's 2006 Green Paper endorsed the findings of 
the Kok Report, thereby validating the idea of segmentation as a result of overly protective regulation of the standard employment relationship; ${ }^{11}$ the Commission currently still supports the view that segmentation is a 'typical outcome of strict EPL for open-ended contracts', although less emphasis is now put on making 'more options' available to employers, with regard to non-standard work. ${ }^{12}$ The issue of segmentation was thus mainly reduced to a risk of 'two-tier' labour markets predominantly imputed to the scope and strictness of dismissal laws: this approach, however, seems to oversimplify the several origins and aspects of segmentation.

In his recent ILO paper, Deakin shows how labour market segmentation has been explained through, or related to, different causes, including policies implemented by employers such as those establishing internal labour markets, often enhanced by the existence of 'asset-specific' capabilities, ${ }^{13}$ or the practices of those employers who set wages above the market-clearing point or offer job security in order to incentivise their workers, particularly when monitoring the workforce is too expensive or inaccurate (efficiency wage theory).${ }^{14}$ In these cases, it has indeed been argued that it is possible for 'laws that require just cause to increase efficiency' and reduce segmentation rather than foster it. ${ }^{15}$

The European Commission and several other institutions and commentators have disregarded most of the findings of these theories and have focused instead on a particular explanation of segmentation, based on the so-called 'insider-outsider' theory, namely a partial elaboration of efficiencywage theory that-as will be explored further below-stresses the role of

${ }^{11}$ EU Commission, Modernising Labour Law, (n.7). See S. Sciarra, 'EU Commission Green Paper 'Modernising labour law to meet the challenges of the 21st century' (2007) 36 Industrial Law Journal 375-382.

${ }^{12}$ EU Commission, 'Labour Market Developments in Europe 2012' (European Economy $5 \mid 2012)$.

${ }^{13}$ P. Doeringer and M. Piore, Internal Labor Markets and Manpower Analysis (Washington D.C.: Manpower Administration (DOL) Office of Manpower Research 1970); O. Williamson, O., M. Wachter and J. Harris, 'Understanding the Employment Relation: The Economics of Idiosyncratic Exchange’ in (1975) 6 Bell Journal of Economics and Management Science 250-278.

${ }^{14}$ See G. Calvo, 'Quasi-Walrasian Theories of Unemployment' (1979) 69 American Economic Review 102-107; S. Bowles, Competitive Wage Determination and Involuntary Unemployment: A Conflict Model (The University of Massachusetts at Amherst, Department of Economics 1981); J. Yellen, 'Efficiency Wage Models of Unemployment' in (1984) 74 American Economic Review 200-205; C. Shapiro and J. Stiglitz, 'Equilibrium Unemployment as a Worker Discipline Device' (1984) 74 The American Economic Review 433-444.

${ }^{15}$ D. Levine, 'Just-Cause Employment Policies in the Presence of Worker Adverse Selection', (1991) 9 Journal of Labor Economics 294-305. 
trade unions in causing segmentation; ${ }^{16}$ in addition, particular concern is devoted to the role of the full-time, open-ended, standard employment relation (SER) as a cause of segmentation: this was also a main concern of legal theories regarding segmentation. ${ }^{17}$ The EU Commission approach on this issue seems somehow to merge some findings of 'insider-outsider' theories with those of the legal SER theories, with workers employed under an SER being labelled as 'insiders'. Legal protections granted to these workers are then indicated as the principal cause of segmentation; reforms aimed at balancing these protections with those provided for non-standard workers are thus nowadays advocated and enacted in order to combat dualism of the labour market. This approach may, however, prove flawed for several theoretical and practical reasons, as it will be shown below: as we shall see, recent reforms in EU Member States provide good examples of how the mainstream approach to labour market segmentation, shared and endorsed by EU institutions, can turn out to be counterproductive. ${ }^{18}$

\section{CAN LEGAL REGULATION ACTUALLY GENERATE 'DUALISM' IN LABOUR MARKETS?}

Before giving an overview of the legal measures adopted in different EU Member States currently facing serious economic downturn in order to combat dualism in the labour market, it is necessary to discuss more deeply the idea that 'dualism' arises chiefly as a direct result of the scope of the legal rules governing standard employment relationships and, in particular, the regulation of dismissal. It has been mentioned above that the mainstream approach to segmentation-endorsed by the EU Commission-couples elements of 'insider-outsider' economic theories with the findings of some legal theories that focus on the relevant role of the standard employment relationship; under this approach, workers employed under a standard employment relationship are often referred to as 'insiders'. As argued in the previous section, this approach tends to ignore the results of other economic

\footnotetext{
${ }^{16}$ A. Lindbeck and D. Snower, 'Insiders versus Outsiders' (2001) 15 Journal of Economic Perspectives 165-188; A. Lindbeck and D. Snower, 'Cooperation, Harassment and Involuntary Unemployment: An Insider-Outsider Approach' (1988) 78 American Economic Review 167-188.

${ }^{17}$ See references in S. Deakin (n.6).

${ }^{18}$ This risk is by no means limited to the EU institutions' approach to labour market segmentation: it has indeed been argued that the whole internal devaluation policy imposed to some EU Member States may have counterproductive effects, see. K. Armingeon and L. Baccaro, 'Political Economy of the Sovereign Debt Crisis: The Limits of Internal Devaluation' (2011) 41 Industrial Law Journal 254-275.
} 
theories concerning segmentation of the labour market and of legal theories that warn against over-estimating the role of law in influencing other social systems such as the economic one: ${ }^{19}$ legal rules and their revisions do not mechanistically influence the economic system or drive changes in it.

In the light of this point, presenting the regulation of standard employment contracts and particularly the relevant regulation of dismissal as the main cause of segmentation in the labour market is unconvincing. One might indeed argue that the very idea of a clear-cut 'dualism' in the labour market of modern advanced economies is an oversimplification: deeming 'insiders' all workers hired under a standard employment contract and subject to dismissal regulation, for instance, on the one hand overlooks substantial differences in working conditions among these workers, and, on the other, disregards many extra-legal factors affecting these conditions. For example, working conditions vary widely according to the geographical location of the firm (e.g., urban or rural region, developed or depressed area within a country) or to its size (one can hardly compare, in this respect, a company with a workforce of 100 people and one with a workforce of 1,000, although they would be subject to the same dismissal regulation in most of the jurisdictions differentiating dismissal regimes on the basis of the workforce's size, such as Italy, Spain and Germany). In addition, working conditions often differ depending on the ownership and corporate structure of the employer and - to some extent - also according to its nationality: work organisations and HR cultures can vary significantly between a family-run enterprise and companies belonging to a multinational group.

Assuming the labour market to be dual also seems to underestimate differences depending upon the level of professionalism, the nature of the job tasks carried out and the relevant classification or role within a company or, to stay with the personal characteristics of employees, their skills and their 'employability' within the labour market, or their level of education. Working conditions may significantly be affected by the degree of unionisation within a company, the presence of trade unions and employees' representative bodies at the workplace, the existence and quality of labour relations at the shop or enterprise level. Even more, it is impossible to overlook the application of sector- and/or enterprise- or shop-based collective

${ }^{19}$ See S. Deakin and R. Rogowski, 'Reflexive Labour Law, Capabilities, and the Future of Social Europe' in R. Rogowski, R. Salais and N. Whiteside (eds.): Transforming European Employment Policy: Labour Market Transitions and the Promotion of Capability (Cheltenham: Edward Elgar 2011); R. Rogowski, Reflexive Labour Law in the World Society (Cheltenham: Edward Elgar 2013); S. Deakin (n.6). 
agreements and-ceteris paribus-agreements at the level of the economic sector or industry: we could hardly explain, otherwise, outsourcing practices motivated by the desire to change the applicable collective bargaining agreements.

For all these reasons, it may be simplistic to represent advanced economies' labour markets as dual as a function of the regulation of dismissal. Also, it is unrealistic to define as 'insiders' those workers who, albeit falling within the scope of unfair dismissal protection, carry out an unskilled repetitive and/or manual job, possibly employed by firms with little or no unionisation or those workers to whom no collective agreements or 'minor' collective agreements apply. Accordingly, it is not convincing to see legal protection against dismissal as a breakpoint for working conditions in labour markets, regardless of the type of remedy that may be awarded under the relevant legal system: working conditions vary widely irrespective of the scope of legal protection on the basis of circumstances that have little or nothing to do with legal regulation, while the extent to which the legal reforms currently addressed to segmentation may alter those conditions could be very limited.

\section{4. 'INSIDER-OUTSIDER' MODELS AND CONTINENTAL EUROPEAN UNIONISM: PLEASE HANDLEWITH CARE!}

Segmentation, furthermore, undoubtedly also affects labour markets of countries where no strong or general rules restricting dismissals exist, such as the USA. ${ }^{20}$ It is noteworthy that the scientific debate around the conflicts of interests between outsiders and insiders and its effects originally developed in the USA and that the relevant literature does not focus on the scope of dismissal regulation; it traditionally emphasised the role of unions and now also stresses, more generally, the replacement costs that companies incur in replacing insiders with outsiders. Replacement costs include 'the costs of hiring, firing and providing firm-specific training, but further costs can arise from the attempts of insiders to resist competition with outsiders by refusing to cooperate with or harassing outsiders who try to underbid the wages of incumbent workers. ${ }^{21}$

\footnotetext{
${ }^{20}$ Even if some restrictions on dismissal exist in almost all the states of the USA, see, D. Autor, 'Outsourcing at Will: The Contribution of Unjust Dismissal Doctrine to the Growth of Employment' (2003) 21 Journal of Labor Economics 1-42.

${ }^{21}$ A. Lindbeck and D. Snower, 'Insiders versus Outsiders' (n.16).
} 
These models concentrate on the features of the US labour market and mainly refer to the traditional US model of industrial relations, a particularly 'exclusive' model, historically centred on the male breadwinner and that, in the past, showed a potentially discriminatory character against women and minorities. The 'insider-outsider' literature often refers to what the insiders 'do' or 'try to do' to improve their position at the expense of outsiders and/or the employer, as if they constituted an entirely homogeneous social entity, capable of behaving 'as one single person'. It seems evident that these models were designed by making reference to 'occupational' and mainly enterprise- or shop-based trade unionism, traditionally making use of union-shop clauses: under this trade union model, it is theoretically possible to coordinate actions of workers already employed against those seeking employment, especially if the latter were willing to accept worse working conditions than the existing ones.

With many reservations, it could then be argued that the insider-outsider' models might provide an account of some features of the US' industrial relations system. Those same theories, however, are hardly applicable to the reality of labour markets in continental Europe, where trade union movements historically follow very different union traditions and labour market strategies, based on 'inclusive' policies and where trade unions are traditionally organised on a national, multi-employer or cross-sectoral basis. It has indeed been argued that general unions organising workers across the occupational lines may counter segmentation in the labour market. $^{22}$ It seems unrealistic to imagine the insiders acting in a co-ordinated fashion to the detriment of outsiders in continental European labour markets; where trade-union action is predominantly carried out on a multiemployer basis, fulfilling systematic marginalisation against outsiders would be much more complicated, also from a reputational stance. Even more difficult is to imagine such marginalisation as carried out by insiders if they were defined simply as those who fall within the scope of protection against unfair dismissal, given the heterogeneous experiences of these workers and of their conditions of work and the variety of relevant occupational or sectoral conditions.

Moreover, it must again be noted that these theories do not focus on a single aspect of segmentation as a dividing factor. Indeed, according to

${ }^{22}$ W. Sengenberger, 'Labour Market Segmentation and the Business Cycle', in F. Wilkinson (ed.), The Dynamics of Labour Market Segmentation (London: Academic Press 1981); S. Deakin (n.6). 
the relevant literature, 'the insider-outsider distinction provides insight on a wide number of divides: employed versus unemployed workers, formal versus informal sector employees, employees with high versus low seniority, unionised versus nonunionised workers, workers on permanent versus temporary contracts, skilled versus unskilled workers, the short-term versus the long-term unemployed, and so on.23

Also for this reason, identifying insiders and outsiders within labour markets on the basis of the scope of the rules restricting dismissal is not convincing.

\section{REFORMS OF LABOUR MARKET LEGISLATION AS A RESPONSETOTHE CRISIS: A TALE OF DEREGULATION}

After discussing some of the flaws of the mainstream approach to labour market segmentation, it is now time to evaluate how the policies allegedly aimed at combating dualism have been implemented in different European countries. It is worth noting that, more often than not, lawmakers and policy makers did not present recent national reforms as mere deregulatory policies. It is not easy to tell whether this was due to the fact that mere deregulatory policies are 'politically indigestible', particularly in certain countries, or also because their economic effects are highly controversial. ${ }^{24}$ However, the scope and aim of recent reforms was, in general, professedly linked to a sort of redistribution of employment protection between insiders and outsiders of labour markets rather than to an overall reduction of this protection.

In Italy, for instance, the purported goal of lawmakers was a general reshaping of labour protection in order to address the issue of dualism in the labour market. This was meant to be done by reviewing the existing regulation of non-standard forms of employment. According to the very first Article of the relevant Act, the reform was aimed at 'redistributing workers' protection more equitably, on the one hand by countering the misuse of legal schemes already introduced in order to provide flexibility [in the labour market], on the other hand by adapting dismissal regulations to the changed

${ }^{23}$ A. Lindbeck and D. Snower, 'Insiders versus Outsiders' (n.16).

${ }^{24}$ See S. Deakin and P. Sarkar, 'Assessing the Long-Run Economic Impact of Labour Law Systems: A Theoretical Reappraisal and Analysis of New Time Series Data' (2008) 39 Industrial Relations Journal 453-487; D. Howell, D. Baker, A. Glyn and J. Schmitt, 'Are Protective Labor Market Institutions at the Root of Unemployment? A Critical Review of the Evidence' (2007) 2 Capitalism and Society $1-71$. 
[business] environment'. This Article, ${ }^{25}$ then, seems to sanction an 'exchange' between greater flexibility in the standard employment relationship of insiders, gained by loosening protections against dismissal, and less flexibility at the margin, to better protect the outsiders, with the purpose of reducing the dualism of the labour market. Similarly, the preamble to the Spanish reform of 2012 preamble declared that its provisions aim to 'enhance the efficiency of the labour market as it is linked to the reduction of labour dualism, with measures affecting chiefly the termination of employment contracts. ${ }^{26}$

The EU Commission - unlike other international institutions ${ }^{27}$ - does not openly call for deregulation of labour markets but stresses instead the need to maintain recent reforms at Member State level which profess to be aimed at combating segmentation, 'resisting the temptation of backtracking'. In particular, according to the Commission, 'the reforms that contributed to reduce the protection between regular and fixed-term contracts should not be reversed, and the mistake made in past decades of relying excessively on easy conditions for fixed-term employment to stimulate job creation should be avoided to avoid perpetuating segmented labour market structures' ${ }^{28}$

Notwithstanding these statements of principle, the legal measures put in place to counter dualism in the labour market can nonetheless be called into question: in particular it can be argued that, in practice, these measures amounted to an overall 'deregulation' rather than to a reduction of the gap

${ }^{25}$ Article 1, 1. 28 Giugno 2012, n.92.

${ }^{26}$ Article II, Real Decreto-ley 3/2012, de 10 de febrero, de medidas urgentes para la reforma del mercado laboral.

${ }^{27}$ See OECD, Economic Policy Reforms 2014: Going for Growth (Paris: OECD), expressly stating that 'strict employment protection legislation (EPL) makes firms more reluctant to hire, especially in a context of an uncertain recovery' and calls on Italy, Spain, Portugal and Slovenia to reduce 'uncertainty and costs related to the judicial procedures, as well as to ease conditions for lay-offs', although other OECD studies, such as R. Bouis et al. (n.4), admit that 'reducing job protection on regular contracts is not found to have any statistically significant effects on aggregate employment, consistent with theoretical and empirical priors'. A clear deregulatory approach is also traditionally followed by the World Bank and the IMF; for a critical review of this approach and of the relevant supporting economic literature see S. Deakin and P. Sarkar (n.24), D. Howell et al. (n.24) and A. Perulli and V. Speziale 'L'articolo 8 della legge 14 settembre 2011, n. 148 e la 'rivoluzione di Agosto' del Diritto del lavoro' WP CSDLE 'Massimo D'Antona' IT-132/2012. For a critical analysis of the methodology used by the OECD to assess the alleged 'strictness' of the employment protection legislation, see R. Artoni, M. D'Antoni, M. Del Conte and S. Liebman, 'Employment Protection Systems and Welfare State Models: A Comparative Study' (2006) available at http://papers.ssrn.com/sol3/papers.cfm?abstract id=895095 (accessed 9 April 2014).

${ }^{28}$ EU Commission, 'Labour Market Developments in Europe 2012' (European Economy 6/2013). 
between the protection of supposed 'insiders' and 'outsiders'. The following subsections show how recent reforms in several EU Members States loosened unfair dismissal regulation but did not appreciably increase protections for non-standard employees. Moreover, it will be argued that other reforms endorsed by the EU Commission, aimed at the decentralisation of collective bargaining systems in different countries, may weaken the 'inclusive' nature of industrial relations systems of continental Europe, potentially leading to the marginalisation of non-standard workers.

\section{A. The Material Loosening of Dismissal Regulation: Levelling-down Protection of 'Insiders'}

In Italy, since the mid-1990s, the issue of segmentation is more often than not referred as a matter of 'dualism' between the labour market(s) of 'protected' and 'non-protected' workers depending on the scope of the socalled 'tutela reale' against unfair dismissal, provided by Article 18 of Law n. 300/1970 (Statuto dei Lavoratori): insiders are deemed those who are protected by Art. 18, any other worker being an outsider, regardless of the nature of their working relationship (self-employed, temporary or permanent employment). ${ }^{29}$

Protection against unfair dismissal varies significantly in Italy, depending on the size of the workforce employed within a single work unit or by the same employer. If the employer has 61 or more employees in Italy, or 16 or more employees in a single work unit, a stronger unfair dismissal regime applies. Under this regime, in case of unfair dismissal, before the 2012 labour market reform, the employer was ordered to both reinstate the employee under the original contract and to pay uncapped damages amounting to the employee's salary between the date of dismissal and the date of actual reinstatement (but with a minimum of five months' salary). This regime was provided by Article 18 of the Statuto dei Lavoratori and was normally referred as 'tutela reale', where 'reale' stood for both 'effective' and 'real', since reinstatement was seen as a much stronger protection relative

\footnotetext{
${ }^{29}$ See P. Ichino, Il lavoro e il mercato. Per un diritto del lavoro maggiorenne (Milano: Mondadori 1996); id., Inchiesta sul lavoro. Perché non dobbiamo avere paura di una grande riforma, (Milano: Mondadori 2011). For a critical review of this approach see F. Carinci, “"Provaci ancora, Sam": ripartendo dall'art. 18 dello Statuto' WP CSDLE 'Massimo D’Antona' IT - 138/2012; M.T. Carinci, 'Il rapporto di lavoro al tempo della crisi: modelli europei e flexicurity "all'italiana" a confronto' (2012) 136 Giornale di Diritto del Lavoro e di Relazioni Industriali 527-572; V. Speziale, 'La riforma del licenziamento individuale tra diritto ed economia' (2012) Rivista italiana di Diritto del lavoro 521-566.
} 
to monetary sanctions, almost giving rise - in theory - to something like a 'property right' in a given job.

Since the 2012 labour market reform, this regime has been diluted. Article 18 of the Statuto dei Lavoratori now provides for reinstatement on top of uncapped damages only in the case of discriminatory or retaliatory dismissal. ${ }^{30}$ Within the scope of the 'tutela reale', these remedies were previously provided in case of unfair dismissal for either disciplinary matters or economic/redundancy reasons. Remedies are now different for disciplinary and economic dismissals: in both of these cases, however, the role of reinstatement and the amount of damages are significantly limited compared with the pre-2012 regime.

By way of example, reinstatement and damages of up to 12 months' salary only apply if the disciplinary dismissal was patently groundless. In any other case of unfair disciplinary dismissal, the employer will have to pay an indemnity of 12 to 24 months' salary, but not reinstate the employee. As to economic dismissal, since the 2012 reform, the court may issue reinstatement only when the dismissal is for an economic or redundancy reason that is visibly non-existent. Even in this case, however, reinstatement would only be an option for the court that could in its place award an indemnity of 12 to 24 months' salary. Courts have not yet developed a coherent set of criteria for reinstatement under the new law: many judgments have however started to shape new criteria, according to which reinstatement is significantly restricted. It can therefore be said that dismissal regulations in Italy were materially relaxed by the 2012 reform: damages in case of unfair dismissal are now strictly capped, and reinstatement is less available: today, it is even debatable whether it still makes sense to label the protection under Article 18 as 'tutela reale': if reale were to be deemed to imply something more than 'effective', hinting at something like 'real', one could argue that making reference to 'tutela reale' is now somehow outmoded.

Dismissal regulation has also been significantly loosened also in Spain and Portugal over the last few years. In Spain, ${ }^{31}$ economic losses, whether current or merely expected, or declining revenues now amount to sufficient

\footnotetext{
${ }^{30}$ See M. Biasi, 'The Effect of the World Crisis on Employment Law and Industrial Relations: report on Italy' forthcoming in Comparative Labor Law and Policy Journal.

${ }^{31}$ See M.E. Casas Baamonde, M. Rodriguez-Piñero y Bravo-Ferrer and F. Valdés Dal Re, 'La nueva reforma laboral', [2012] Relaciones Laborales 1-39; J. Cruz Villalón, 'Los cambios en materia de extinciones individuales en la reforma laboral de 2012' [2012] Relaciones laborales 121-147; J. Gorelli Hernández, 'La reforma laboral de 2012 y su impacto en los despidos individuales' (2012) 115 Temas Laborales 275-314; S. Bentolila, J. F., Jimeno and J. J. Dolado (n.4).
} 
cause for a fair dismissal for economic reasons. Other economic or objective reasons have been more clearly defined and notice of dismissal was reduced from 30 to 15 days. Severance pay for standard employment contracts was cut to 33 days' wages per year of service (it was 45 days before the reform), with a 24-month cap (this removes the distinction between the standard employment contract and the employment-promotion permanent contract, introduced in 1997). ${ }^{32}$ Employers with less than 50 employees can now hire workers under a permanent employment contract (Contrato de Apoyo a Emprendedores) subject to a one-year probation period during which the contract can be terminated without severance pay. After the probationary period, severance pay would apply, which would be equal to 33 or 20 days' wages per year of service respectively if the dismissal is fair or unfair. In a major change, public bodies' authorisation is no longer a requirement for collective dismissals.

In Portugal, ${ }^{33}$ the definition of fair individual dismissal has recently been relaxed: senior employees or employees performing complex tasks may now be dismissed for unsuitability (inadaptação) without there being a need for the introduction of new technology to which the employee is unable to adapt (this was instead a requirement before the reform). Other employees may be dismissed for unsuitability if they fail to achieve previously agreed work objectives. The last-in-first-out tenure rule in case of economic dismissal was also abolished. Severance payments for employees hired after 1 November 2011 were reduced from 30 to 20 days' wages per year of service, ${ }^{34}$ with a cap of 12 months - the minimum amount of 3 months no longer applies - and the employer pays only 10 days' wages, the remaining 10 days being paid by a new employment fund, financed by employers.

Lawmakers in Italy, Spain and Portugal have therefore followed the European institutions' call for reducing protection for standard employees; the next subsection shows, however, that the same cannot be said for the appeal to better protect non-standard work.

\footnotetext{
${ }^{32}$ Workers hired before February 2012 and unfairly dismissed will be entitled to a weighted average of the former 45-day and the new 33-day regimes, with a 720-day cap.

${ }^{33}$ A. Pestana Nascimento, 'A reforma laboral em Portugal' Actualidad Juridica, Especial reformas estructurales / Extraordinario-2012 47-61; A Turrini, 'EPL Reforms in Europe: A Portuguese Way to Single Contract Outcomes?' 2011 at http://www.voxeu.org/article/ labour-market-reforms-lessons-portugal.

${ }^{34} \mathrm{An}$ interim regime was provided for workers hired before 1 November 2011 under which severance payments will be calculated taking into account tenure under the previous regime (until 31 October 2012) and the new one.
} 


\section{B. Reforms of Non-standard Contracts to Combat 'Dualism': Much Ado About (Almost) Nothing}

As already mentioned, recent reforms adopted in several European countries as a response to the economic crisis have loosened unfair dismissal regulation but have not appreciably increased protections for non-standard employees.

In Italy, indeed, the law strengthened protection of parasubordinate 'project work': for instance, project workers' compensation must now comply with minimum compensation levels set out in national collective agreements. Moreover, the law clarified that 'project work' cannot be entered into for the performance of very simple and repetitive tasks. The reform also clarified that, when a proper 'project' is not provided, parasubordinate contracts are to be deemed, under a non-rebuttable presumption, to give rise to a more regular, 'subordinate' employment relationship. A rebuttable presumption of parasubordination was introduced for otherwise non-parasubordinate self-employment when certain conditions apply. According to the classification of legal techniques aimed at addressing segmentation we discussed earlier, ${ }^{35}$ these measures may fall under the first category, as they widen the scope of protective regulation and combat the use of bogus selfemployment (including parasubordination), by attempting to bring some 'grey-area' cases within the scope of employment.

However, the protective elements of these laws should not be overestimated. On the one hand, the law merely restates some principles already applied by the majority of case law; for example, most courts were already applying the presumption of subordination in cases where a proper 'project' did not exist. On the other hand, the really new protections, such as the minimum compensation provisions or the rebuttable presumption of parasubordination, could easily drive employers to resort to other nonstandard contracts that have been further liberalised. In particular, the law abolished the need to link fixed-term contracts and temporary agency work to an objective reason for the first contract up to 12 months; according to the main trends in the case law, objective reasons had to be supplied in any case for the use of temporary or fixed-term employment. This is a material liberalisation because most of these contracts are entered into for very short periods. The 2012 reform tried to balance this deregulation by establishing that no extensions of contracts could take place if the relevant objective

\footnotetext{
${ }^{35}$ See S. Deakin (n.6).
} 
reasons had not been supplied, and by increasing the duration of the minimum 'interruption periods' between the previous fixed-term employment contract expiring and a new one beginning with the same employee. Before the 2012 reform, these periods were 10 days and 20 days, respectively, for contracts under and over 6 months; they were increased to 60 and to 90 days respectively. In 2013, however, lawmakers made extensions of fixed-term contracts legitimate up to 12 months in total and decreased the mandatory interruption periods to their original duration. In 2014, moreover, the Government approved a new reform under which fixed-term and TAW contracts have no longer to be justified with specific reasons. In addition, the parties can prolong the duration of the contract with no significant restrictions: up to five extensions are now permitted. As a consequence, the use of fixed-term and temporary agency work contracts has now been dramatically liberalised in comparison with the pre-2012 regime: this is plainly inconsistent with the purported aim of the 2012 reform. If one adds this liberalisation to the loosening of unfair dismissal regulation, the result is a clear levelling down of employment protection that in no way can be deemed to be balanced by the renewed regulation of parasubordination. If we come back to Deakin's categorisation, it could be said that the recent reforms of the Italian labour market fall somehow both under the first category (with more defined classifications of parasubordination and self-employment) and under the second category (with a reduction of protections for both standard employment and some crucial non-standard contracts).

Inconsistency between the alleged purpose of the reforms and their actual scope, however, is not limited to Italy. In Portugal, severance payments for fixed-term employees were reduced from 36 or 24 days' wages per year of service (respectively for contracts shorter or longer than 6 months) to 20 days: the reform therefore significantly affects workers with shorter contracts, with their severance cut by more than one third. In Spain, severance pay will be slightly increased from 8 to 12 days' wages per year of service for fixed-term employees.

It can, therefore, be said that the part of the reforms concerning nonstandard workers was either at odds with with the alleged purpose of bettering their conditions (Italy and Portugal) or simply very feeble (Spain). In Spain, however, an important reform had been passed in 2007 introducing significant protections for economically dependent self-employed workers. ${ }^{36}$ This could be seen as bringing the set of Spanish reforms adopted in the last decade within both the first and the second of Deakin's categories, with legal

${ }^{36}$ Ley 20/2007, de 11 de julio, del Estatuto del trabajo autónomo (LETA). 
techniques aimed at widening the scope of protective legislation coupled with a significant levelling-down of the protection for standard employment and a weak levelling-up concerning non-standard workers. ${ }^{37}$ It may however be incorrect to lump the 2007 and the 2010-2011 reforms together, as they were adopted in a very different economic and institutional situations; in any event, the recent weakening of the regulation governing dismissal of standard employees seems to outweigh the benefits introduced by the Spanish lawmakers with regard to atypical contracts. ${ }^{38}$ One can then argue that the alleged reduction of dualism in the Spanish labour market was mainly carried out at the expense of standard employment and was not balanced by a corresponding levelling-up of the protections for the remaining workforce. The same can be said about the latest reforms in Italy and Portugal. ${ }^{39}$

\section{Decentralisation of Collective Bargaining and the Risk of Marginalisation of Non-standard Workers}

Up to this point, it has been argued that both the current mainstream approach to labour market segmentation and the legal measures adopted in several countries to tackle segmentation seem are unsatisfactory, as they merely amount to an overall reduction of employment protection of both 'insiders' and 'outsiders' Meanwhile, other recent labour law reforms unrelated to the scope of standard and non-standard work contracts could spur further marginalisation of outsiders.

In the past few years, several measures aimed at decentralising collective bargaining have been taken in different European countries: ${ }^{40}$ an issue that seems to have been disregarded, in this respect, is how decentralisation could affect the conduct of trade unions towards non-standard workers and 'outsiders' in general. As we saw in Section 4 above, the organisation of trade unions on a general and/or multi-employer basis in continental Europe has driven unions towards a traditionally 'inclusive' approach.

\footnotetext{
${ }^{37}$ The last reforms in Italy, Spain and Portugal also affected the system of unemployment benefits and, in some cases, also involved monetary incentives /subsides aimed at the 'stabilization' of workers: it could thus be said that they also partially fit in the third set of legal techniques categorized by Deakin.

${ }^{38} \mathrm{M}$. Rodriguez-Piñero Royo 'La forza del mercato: le riforme del diritto del lavoro spagnolo durante la crisi finanziaria mondiale’ (2013) 137 Giornale di Diritto del Lavoro e di Relazioni Industriali 91-106.

${ }^{39}$ See also S. Deakin and A. Koukiadaki (n.8).

${ }^{40}$ See essays published in R. Blanpain (ed.), Decentralizing Industrial Relations and the Role of Labor Unions and employee Representatives (The Hague: Kluwer Law International 2007).
} 
A different, 'exclusive' approach would be difficult to implement on a multi-employer basis and could also bring about reputational damage for trade unions.

'Exclusive' approaches to workers' protection are likely to arise from single-employer based and/or 'occupational' unionism and collective bargaining, possibly leading to marginalisation of outsiders. It goes without saying that decentralisation of collective bargaining does not necessarily convey these adverse effects and that they could also be prevented through an effective management of decentralisation. European institutions, however, apparently overlooked this point when they endorsed a controversial 2011 reform regarding the decentralisation of the Italian collective bargaining system. ${ }^{41}$ Significant steps towards regulated decentralisation had already taken by the social partners in the first part of 2011. A cross-sector framework agreement (the 2011 agreement) had been concluded between the most representative union confederations and the main employers' association, under which national industry-wide collective agreements would make provision for the devolution of rulemaking to firm-level agreements. In August 2011, however, at the height of the financial crisis affecting Italian public debt, the government approved by decree a provision (Article 8, Decree 138/2011-Law 148/2011) regulating the decentralisation of collective bargaining agreements in a very different way from the 2011 Agreement. In particular, Article 8 stated that firm-level agreements could derogate from, and would prevail over, the provisions of employment laws and of national collective bargaining agreements, in striking contrast to the 2011 Agreement, according to which national agreements would decide methods of devolution to decentralised agreements. In a major change of approach, Article 8 allows enterprise or shop-level agreements to regulate non-standard work such as fixed-term employment, part-time employment or temporary agency work, or parasubordinate work and self-employment. ${ }^{42}$ Moreover, decentralised collective agreements may in future derogate from the statutory joint-liability regime provided in favour of workers of a contractor or subcontractor in case of outsourcing and, most notably, they may also override legal protections against unfair dismissal. Nothing in Article 8 prevents decentralised agreements from derogating from these protections only

${ }^{41}$ EU Commission, Commission Staff Working Document, In-Depth Review for ITALY in accordance with Article 5 of Regulation (EU) No 1176/2011 on the prevention and correction of macroeconomic imbalances, SWD(2012) 156 final.

${ }^{42} \mathrm{See}$, M. Biasi (n.30). 
for new employees; the statutory protections of the incumbent workforce could also be affected.

Enabling collective agreements to deregulate non-standard work is not a novelty for the Italian labour market: similar powers had already been conceded by laws dating back to the mid-1980s. It can be argued that the Italian social partners did not use the powers provided by these laws to marginalise outsiders, given the largely 'inclusive' approach to labour regulation of Italian trade unions. Yet the power to derogate from otherwise binding standards was, at that point, limited to national collective agreements, and they were much narrower in scope than those more recently conceded to enterprise- or plant-level agreements under Article 8. This was also the appraoch taken in the 2012 reforms. The 2013 reforms, by contrast, granted the same powers to decentralised agreements. Article 8 was neither repealed nor amended by the 2012 and 2013 reforms. ${ }^{43}$

The risk of Article 8 encouraging opportunistic conduct against outsiders at the workplace cannot be ruled out. It is worth noting that in this case 'outsiders' are not simply falling outside the scope of dismissal regulation: firm-level collective agreements may now operate to the detriment of employees of contractors or subcontractors who could be covered by dismissal protection under Article 18 of the Statuto dei Lavoratori. It can therefore be argued that, despite their claimed goal of achieving a better balance between the situation of insiders and outsiders in the labour market, recent reforms in Italy are worsening the position of both groups.

Again, it must be stressed that decentralisation of collective bargaining cannot automatically be associated with opportunistic behaviour of standard employees: in northern Europe, for instance, flexibility measures are specifically provided via collective bargaining, in particular through a delegation from sector-level to firm-level agreements. This provides the system with and appreciable degree of flexibility within

\footnotetext{
${ }^{43}$ On September 2011 the most representative trade unions and employers' association agreed that they would not make use of collective agreements regulated by Article 8 and that they would refer instead to the industrial relation framework set out by the 2011 agreement mentioned above. Recent empirical research shows, however, that the same social partners concluded several enterprise or shop-level agreements under Article 8, even if-as a matter of practice - they avoided making explicit reference to this Article in the wording of these agreements; see L. Imberti 'A proposito dell'articolo 8 della legge n. 148/2011: le deroghe si fanno, ma non si dicono’ (2013) 138 Giornale di Diritto del Lavoro e di Relazioni Industriali 255-272.
} 
a general system of regulation and it has not lead to a marginalisation of atypical workers, even if also these systems may somehow begin to creak. ${ }^{44}$

In other European countries, such as Italy, Spain and Portugal, however, the recent reforms uncoupled firm-level collective bargaining from industry-wide agreements and legal regulations. ${ }^{45}$ In Spain, worker committees independent from unions were authorised to enter into firm-level agreements. ${ }^{46}$ Similar measures were put in place in Portugal and Greece. ${ }^{47}$ The risk in allowing firm-level collective agreements to operate outside the general framework of labour law regulation is that it will further undermine workers' protection. If unions are discouraged from adopting solidaristic and inclusive approaches to bargaining, non-standard workers will be further disadvantaged.

\section{6. 'FLEXIBILITY-AT-THE-MARGIN': IS LABOUR MARKET SEGMENTATION JUST A FEATURE OF OUR TIMES?}

Our review of the reforms adopted in several EU Member States and endorsed by the EU Commission has shown that lawmakers, despite supposedly aiming at reducing segmentation of labour markets, have matter of fact followed a clear deregulatory path that has reduced protection for both

\footnotetext{
${ }^{44}$ See M. Rönnmar and A. Numhauser-Henning, 'Flexicurity, Employability and Changing Employment Protection in a Global Economy. A Study of Labour Law Developments in Sweden in a European context' (Lund University 2012). For Denmark, see J. Due and J. S. Madsen, 'The Danish Model of Industrial Relations: Erosion or Renewal?' (2008) 50 Journal of Industrial Relations 513-529.

${ }^{45}$ The EU Commission welcomed decentralisation of collective bargaining systems also in Spain and Portugal. See EU Commission, Commission Staff Working Document, Assessment of the 2012 national reform programme and stability programme for SPAIN, SWD(2012) 310 final and EU Commission, Commission Staff Working Document, Assessment of the 2012 national reform programme and stability programme for PORTUGAL, SWD(2012) 324 final. See also S. González Ortega, 'La negociación colectiva en el Real Decreto-Ley de medidas urgentes para la reforma del mercado laboral' (2012) 115 Temas Laborales 85-134.

${ }^{46}$ See F. Navarro Nieto, 'Collective Bargaining in Spain: the Reform of the Regulatory Framework' (2012) 1 E-Journal of International and Comparative Labour Studies, 27-45.

${ }^{47}$ For Portugal, see A. C. Valente and P. Marques, 'An evaluation of the social and employment aspects and challenges in Portugal' (2014) European Parliament. Directorate General for Internal Policies. Economic Governance Support Unit (EGOV). Policy note. PE 497.759. For the Greek measures, see H. Voskeritsian and A. Kornelakis, 'Institutional Changes in Greek Industrial Relations in an Era of Fiscal Crisis' (2011) 52 Grese Paper. Hellenic Observatory Papers on Greece and East Europe. London School of Economics and Political Science
} 
standard and non-standard workers. Moreover, when advocating decentralisation of collective bargaining, European institutions and policy makers tend to overlook its potential detrimental effect on atypical workers. This, however, does not come as a surprise: following a narrative whereby segmentation is a function of the scope of standard employment relation and all the workers covered by dismissal regulation are regarded as insiders', one may overlook other common elements of differentiation across the labour market, such as the ones described in Section 3.

As we have seen, the mainstream approach and the related insider-outsider' narrative neglects consideration of other theories on segmentation of the labour market that seem to provide for a more comprehensive account of this issue. It can be noted, for instance, that segmentation is not a recent occurrence that could be chiefly imputed to the 'flexibility-at-the-margin' policies adopted in the last decades. The existence of a 'primary' and a 'secondary' labour market is not a phenomenon of our times: from the dawn of industrialisation certain categories of workers have enjoyed better economic and regulatory conditions in comparison with others in a weaker bargaining position; a difference in the condition of workers involved in subcontracting or other forms of business dis-integration, such as home workers, has always existed. ${ }^{48}$ It could be said, however, that, during the last forty years, a mainstream business trend towards de-concentration of big firms and outsourcing can be seen, which has given rise to business structures following a 'core/ periphery' pattern: firms have tended to progressively divest those parts of their production cycle that are not relevant to their core business. ${ }^{49}$ This has swollen the ranks of 'contingent' or 'marginal' workforce, hired under contractual arrangements that are typical of vertical disintegration, such as contracting or subcontracting or non-standard working contracts. ${ }^{50}$ By contrast, workers employed within core business' sectors tend still to be offered significant job stability through open-ended employment contracts.

Very often, the contingent workforce is employed at the margin of business production, executing activities that require a low level of professionalism or skills. These activities normally display low asset-specificity and require

${ }^{48}$ See L. Mariucci, Il lavoro decentrato. Discipline legislative e contrattuali, Milan, 1979.

${ }^{49}$ J. Atkinson, 'Manpower Strategies for Flexible Organizations' (1984) August Personnel Management 28-31; Id. Flexibility, uncertainty and Manpower strategy, (Brighton: Institute of Manpower Studies 1985, Report n.89). See also, L. Hunter, A. McGregor, J. Maclnnes and A. Sproull, 'The "Flexible Firm": Strategy and Segmentation' (1993) 31 British Journal of Industrial Relations 383-407.

${ }^{50} \mathrm{H}$. Collins, 'Independent Contractors and the Challenge of Vertical Disintegration' (1990) 10 Oxford Journal of Legal Studies 353-380. 
limited training of the workforce, significantly reducing the cost of replacing a worker assigned to them. Non-standard workers such as fixed-term employees and those employed on TAWs may be particularly affected in this respect, since-according to labour market statistics-they tend to carry out unskilled work. ${ }^{51}$ For this reason, it does not seem possible to improve the working conditions of the contingent workforce by lowering the levels of protection of standard employees. It is arguable that loosening, or eliminating, protection against dismissal would lower the incentive to resort to non-standard contracts and to subcontracting, although it should be remembered that subcontracting did exist long before the introduction of dismissal regulations in several countries. ${ }^{52}$ However, this would not necessarily increase the contingent workforce's job stability, since its low asset-specificity makes the replacement of marginal workers easy and cheap.

Core/periphery models may represent an explanation of labour market segmentation that is more accurate than describing the labour market as divided between insiders and outsiders on the basis of the scope of dismissal regulations: entrepreneurial strategies aimed at curbing production costs and making business organisations leaner can be seen as one of the fundamental causes of segmentation even if it is not taken into account by the mainstream narrative on this topic.

\section{ALL PERMANENT, ALL PRECARIOUS: THE 'SINGLE PERMANENT CONTRACT'AND ITS FLAWS}

In the light of what has been observed in the previous part, flattening employment protections in order to reduce the gap between standard

\footnotetext{
${ }^{51}$ This is a longstanding occurrence in the Italian labour market, see L. Cavallaro, D. Palma, 'Come (non) uscire dal dualismo del mercato del lavoro: note critiche sulla proposta di contratto unico a tutele crescenti' [2008] Rivista Italiana di Diritto del Lavoro 507-528. See also G. Alteri, L. Birindelli, F. Dota and Giuliano Ferrucci 'Un mercato del lavoro sempre più "atipico": scenario della crisi' (IRES CGIL Rapporto di Ricerca n. 08/2011) reporting that $71 \%$ of Italian TAWs were carrying out unskilled working activities in 2011. According to Rapporto Isfol 2012, Le competenze per l'occupazione e la crescita (Rome: ISFOL 2012), temporary workers show higher rates of overqualification. Low-skill workers are overrepresented among fixed-term in Spain, according to S. Bentolila, J. F. Jimeno and J. J. Dolado (n.4). Also in the USA., non-standard workers tend to carry out unskilled jobs: see data in Kellberg, 'Flexible Firms and Labor Market Segmentation: Effects of Workplace Restructuring on Jobs and Workers', (2003) 30 Work and Occupations 154-175.

${ }^{52} \mathrm{G}$. Giugni, 'Organizzazione dell'impresa ed evoluzione dei rapporti giuridici. La retribuzione a cottimo', in (1968) Rivista di Diritto del Lavoro 1-85.
} 
and non-standard workers would not result in better working conditions or higher job stability for marginal workers operating outside employers' core businesses. It is, instead, the EU Commission's belief that a 'reduction of segmentation in the labour market [...] could be facilitated by altering employment protection legislation, by for instance extending the use of open-ended contractual arrangements with a gradual increase of protection rights to diminish the existing divisions between those holding atypical and permanent contracts'. According to the Commission, a set of policies to be encouraged in this respect 'includes the adoption of a 'single permanent contract', replacing the existing legal asymmetry between permanent and fixed-term contracts. ${ }^{53}$

The 'single permanent contract' (SPC) has been promoted in different European countries by some economists and lawyers: ${ }^{.4}$ it would be an openended employment contract with a long (on average 2-3 years) probation/ consolidation period during which employees would not be covered by the ordinary protection against unfair dismissal and their contract could be terminated at will, subject to the payment of an indemnity varying upon the relevant length of service.

A significant debate has taken place in the last few years in Spain and Italy concerning the SPC. ${ }^{55}$ Several Bills were presented to the Italian parliament in this respect, but the proposal for the SPC was not included within the most recent reforms. Nonetheless, some measures that may have an impact on the labour market akin to the potential effects of the introduction of a single permanent contract were recently approved in some jurisdictions. In Spain, for example, this is the case of the 'employment contract to support entrepreneurs' (ECSE), a contract whereby a statutory probationary period is in force for one year, irrespective of the job position/role in firms whose workforce is under 50 employees. In Greece, a probationary period of one year, irrespective of the job position and of the workforce size, was

\footnotetext{
${ }^{53}$ EU Commission, Employment in Europe 2010. See also, id., Labour Market Developments in Europe 2012 (n.12).

${ }^{54}$ O. J. Blanchard and J. Tirole, 'Contours of Employment Protection Reform' (2003) 03-35 MIT Department of Economics Working Paper; P. Cahuc and F. Kramarz, 'De la précarité à la mobilité, vers une sécurité sociale professionnelle' Rapport pour le Ministre de l'Economie et des Finances (2004) La documentation Française; S. Bentolila, J. J. Dolado, J. and F. Jimeno, 'Two-Tier Employment Protection Reforms: The Spanish Experience' (2008) 4 CESifo DICE Report; P. Ichino, Inchiesta sul lavoro (n.29); S. Bentolila, J. F., Jimeno, J. J. Dolado (n.4).

${ }^{55}$ See P. Gete and P. Porchia, 'A Real Options Analysis of Dual Labor Markets and the Single Labor Contract' (2011) MPRA (Munich Personal RePEc) ArchivePaper, No. 34055; L. Zappalà (n.9).
} 
introduced in $2010 .{ }^{56}$ In the UK, the qualifying period before an employee accrues unfair dismissal rights was raised from one to two years in 2012. ${ }^{57}$ These measures may be comparable to the introduction of the SPC as they allow employers to dismiss workers for a long period of time before they acquire full unfair dismissal rights. It is true that the SPC proposals usually provide for a basic severance payment, increasing with the length of service, but these payments will be very low in case of short duration contracts, maintaining the possibility that dismissing employees hired on a short-time basis can easily outweigh the small cost of dismissing a worker before he or she accrues unfair dismissal rights at the end of the probation/qualification period provided by the SPC.

The experience of the Spanish ECSE is relevant in this respect: material subsidies were provided by the law if the workers employed under an ECSE remained in work for at least 3 years. Recent data show, however, that most employers chose to renounce subsidies and entered into an ECSE in order to enjoy the one-year probationary period. ${ }^{58}$ Thus, keeping the possibility of dismissing workers outweighed monetary incentives: this can also provide useful lessons with regard to the SPC, as employers may well opt for paying severance amounts, instead of employing workers until they become entitled to unfair dismissal protection. It goes without saying that this will not always be the case under a SPC regime as employers may not want to disperse firmspecific skills and know-how accrued by their employees, or to avoid the cost of replacing them; ${ }^{59}$ but in the case of unskilled labour and a lack of assetspecificity, replacement costs would be particularly low and thus the incentive to substitute workers before they accrue unfair dismissal rights will be paramount. In such a situation, the risk that unskilled or marginal workers

${ }^{56}$ A. Koukiadaki and L. Kretsos (n.8).

${ }^{57}$ K. D. Ewing, J. Hendy, 'Unfair Dismissal Law Changes - Unfair?' (2012) 41 Industrial Law Journal 115-121; E. McGaughey, 'Unfair Dismissal Reform: Political Ping-Pong with Equality?' (2012) available at http://papers.ssrn.com/sol3/papers.cfm?abstract_id=2014699 (accessed 9 April 2014). Moreover, in the UK (and in Australia), 'no fault dismissal', another measure very similar to the SPC, has recently been proposed: see J. Howe, 'Poles Apart? The Contestation between the Ideas of No Fault Dismissal and Unfair Dismissal for Protecting Job Security' (2013) 42 Industrial Law Journal 122-151.

${ }^{58}$ Data are available at http://www.elconfidencial.com/espana/2013-11-13/exito-del-contratode-emprendedores-el-85-es-para-trabajos-de-un-solo-ano_52576/ (accessed 9 April 2014).

${ }^{59}$ According to J. I. García Pérez and V. Osuna, 'The Effects of Introducing a Single Openended Contract in the Spanish Labour Market' (2011) WP Econ 11.07, Universidad Pablo de Olavide, before the equalization of severance-payment amounts described at Section 5 above, the turnover rate for employees under an employment-promotion permanent contract markedly outdistanced that of standard employees. 
undergo an indefinite series of 'probation/qualifying periods' with several employers and are dismissed before accruing full dismissal rights is very high: those workers would still be trapped in a vicious and permanent circle of precarious work. The SPC could thus prove entirely ineffective in protecting 'outsiders' such as non-standard workers as they, more often than not, carry out low-skilled activities; on the other hand, the SPC would significantly lower the protection of standard workers as they will not be protected against unfair dismissal before the expiry of a probation/qualifying period much longer than in the past (according to some Italian proposals, from $3^{60}$ to 20 years ${ }^{61}$ ).

Moreover, it must be noted that the SPC is actually unlikely to be a 'single' contract replacing all other forms of working contract in the labour market: if one looks at the Italian measures proposing the SPC, for instance, they all maintain the possibility of entering into fixed-term contracts for temporary reasons and into temporary agency work in order to comply with Directive 2008/104/EC. Nor it will be possible to eliminate self-employment arrangements: the Italian proposals, for instance, aim at reregulating self-employment in order to have economically dependent self-employees covered by the SPC legislation on the basis of quantitative remunerative parameters: these legal techniques have, however, been strongly challenged ${ }^{62}$ and would have the effect of merely relocating the borders of the 'grey-area' between a newly deregulated employment and self-employment rather than providing for adequate protections for the latter. Therefore, non-standard working contracts will continue to have material relevance in the labour markets even under an SPC regime. The SPC proposals would then continue to contrast segmentation of the labour market at the expense of standard workers rather than through an increase of non-standard workers protections and job stability: in this respect, then, these proposals materially follow the deregulatory path of the recent reforms aimed at reducing labour market segmentation in European Member States.

\footnotetext{
${ }^{60}$ See d.d.1. 2630/2009 (Camera. Prima firmataria on. Madia); d.d.1. 2000/2010 (Senato. Primo firmatario sen. Nerozzi). See also d.d.1. 4277/2011 (Camera. Primi firmatari onn. Raisi, Della Vedova).

${ }^{61}$ See d.d.1. 1481/2009 (Senato. Primo Firmatario sen. Ichino); 2630/2009; 1873/2009 (Senato. Primo firmatario sen. Ichino); d.d.l 1006/2013 (Primo Firmatario sen. Ichino). This 20-year period would only apply to dismissal for economic reasons, a different, more protective, regulation being provided for other dismissals. See however Section 8 below on the risk of disguised reasons for termination.

${ }^{62}$ See O. Razzolini, 'Defining Economic Dependency on the Basis of Quantitative Remunerative Parameters. Is this the Answer to the Increasing Demand for a Social Contract Law?' (2011) European Journal of Social Law 187-206
} 
The SPC idea was significantly inspired by the French contrat nouvelles embauches: an employment agreement whereby employees could not challenge a dismissal grounded by economic reasons during an initial period of two years. The contrat nouvelles embauches was repealed in France in 2008, after case law had found it in breach of international obligations. In particular, the contrat was held to be an infringement of International Labour Organization (ILO) Convention no. 158 concerning Termination of Employment at the Initiative of the Employer. Pursuant to the Convention, employees have the right not to be dismissed 'unless there is a valid reason' and, in case of termination, there must be a right 'to appeal against that termination to an impartial body'. French case law held that the initial period of two years was not compliant with the convention's provision that allows probation or qualifying periods 'of reasonable duration.63 ${ }^{63}$ The European Commission and other European and international institutions are overlooking the negative experience of the contrat nouvelles embauches when advocating the SPC. This is quite surprising, given that this measure was repealed a very short time after its enactment because of a blatant breach of an ILO Convention; initiatives of Member States aimed at introducing the SPC-particularly if such introduction were encouraged by European institutions-could create a conflict between the labour reforms of those Member States and the ILO protection against dismissal, potentially leading to an awkward clash between international labour standards and measures taken following the recommendations of EU institutions on the one hand, and to significant litigation in different Member States, concerning the legitimacy of the SPC regime, as it could breach the obligations of a country under international treaties, on the other.

\section{PROTECTIONS AGAINST DISMISSAL AS A MEANS OF UNDERPINNING FUNDAMENTAL AND CONSTITUTIONAL RIGHTS}

The repeal of the contrat nouvelles embauches due to its contravention to France's international obligations offers the opportunity to outline some further remarks. One could wonder why the ILO Convention as well as many other international or European treaties or charters and national legislation give so much importance to the right not to be dismissed without

\footnotetext{
${ }^{63}$ See Cour d'Appel de Paris, Arrêt du 9 juillet 2007, RG n.06/06992; Cour de cassation, civile, Chambre sociale, 1 juillet 2008, 07-44.124.
} 
a valid reason. The immediate answer may of course be that regulations against unfair dismissal allow employees to preserve their job and salary as their main source of income. Some justifications for regulating dismissal can also be drawn on the basis of economic theories. ${ }^{64}$ However, from a legal standpoint, other justifications for effective dismissal protections cannot be overlooked: regulation against unfair dismissal can be pivotal in securing the exercise of other rights at the workplace, some of which can very well be fundamental or - in some jurisdictions - constitutional rights.

If no protection against dismissal were provided, employees might be reluctant to make use of rights such as those concerning working time, sick pay, parental protection or even the right to unionise or to participate to industrial actions, since they might be afraid of losing their job were they to do so. For instance, one reason why employers resort to temporary work contracts in Italy, even if - from a legal standpoint - these contracts afford a lower degree of functional flexibility in comparison with a permanent employment relationship may also lie in the fact that, given the temporary nature of these relationship, temporary workers may feel forced to implicitly waive some of their statutory or contractual rights by not exercising them, in order not to displease the employer and try to obtain either an extension or a renewal of their contract. ${ }^{65}$ Regulations granting a certain level of job stability, such as an unfair dismissal regulation, can then prove essential to making other employment and labour rights effective.

A good example in this respect is provided by the case law of the Italian Constitutional Court on the statute of limitation for the payment of salaries. The Civil Code, enacted in 1942, provided for a reduced statute of limitation for claiming unpaid or outstanding salaries. According to the court, the statute of limitation must be held as not running during the course of employment, since 'the fear of being dismissed induces or may induce employees to waive part of their own rights; thus, when such waivers are made during the course of employment, employees cannot be deemed to

\footnotetext{
${ }^{64}$ See P. Ichino, Lezioni di diritto del lavoro. Un approccio di labour law and economics (Milano: Giuffrè 2004) chapters II and X.

${ }^{65}$ V. De Stefano, 'Smuggling-in Flexibility: Temporary Work Contracts and the "Impliicit Threat" Mechanisms. Reflections on a New European Path' (2009) 4 Labour Administration and Inspection Programme LAB/ADMIN Working Document (Geneva: International Labour Organization). See also N. Kountouris 'The Legal Determinants of Precariousness in Personal Work Relations: A European Perspective' (2012) 34 Comparative Labor Law and Policy Journal 21-46.
} 
have acted according to their own free will ${ }^{66}$ This principle finds a significant exception when the employees enjoy effective protection of their job stability because the court can order the reinstatement of an employee: ${ }^{67}$ in this case the fear of losing one's job is presumed to be restrained by strong unfair dismissal protections. This case law, then, shows a very close link between actual protection of job stability and the effectiveness of other rights during the employment: it could be argued that a significant shortcoming of the SPC proposal is overlooking this strong link. This seems to be true even for those SPC proposals providing very strong protection against discriminatory, retaliatory or arbitrary dismissals, the latter being defined under some of these measures as 'those terminations based upon mere whimsical grounds, meaning trivial reasons totally unrelated to the economic, technical, organisational or productive needs of the business. ${ }^{68}$ One of the main aims of the SPC approach is to 'secure' a decision to dismiss employees, by exempting employers from the need to prove a valid reason for dismissal and preventing courts from reviewing the authenticity of such reason: in this case, it would be easy for employers to disguise disciplinary, discriminatory or retaliatory dismissal under any business reason not meeting the very stringent definition of 'whimsical grounds'. SPC regimes may thus fall short of providing effective protection against discriminatory conduct at the workplace: this could lead to a breach of fundamental and human rights concerning discrimination, enshrined in numerous international and European treaties and conventions as well as in many national constitutions.

It is also worth noting that when the qualifying period was first raised to two years in the UK in 1985-a measure that, as argued in the previous section, may have had effects comparable to the introduction of the SPCthe House of Lords found that this regulation had had a disparate adverse impact on women: ${ }^{69}$ in questioning the 2012 increase, it has recently been argued that a risk of disparate impact may now also arise with regard to race and other characteristics such as 'income and education:70 The same concerns can be expressed also with regard to the SPC proposals: employment

\footnotetext{
${ }^{66}$ Corte Costituzionale, 10 giugno 1963, no. 63.

${ }^{67}$ Corte Costituzionale 20 novembre 1969, no. 143; Corte Costituzionale. 29 aprile 1971, no. 86; Corte Costituzionale, 1 giugno 1979, no. 40-44.

${ }^{68}$ d.d.l. 1481/2009; d.d.1. 1873/2009; d.d.1 1006/2013 (n.61)

${ }^{69} R$ (Seymour-Smith) v Secretary of State for Employment, [2000] UKHL 12, [2000] 1 WLR 435 and (1999) C-167/97.

${ }^{70}$ See, E. McGaughey (n.57).
} 
regulations making a significant number of dismissals exempt from the need for a valid reason may thus have both direct and indirect discriminatory outcomes. These concerns may be extended to different approaches to labour market regulation - frequently lumped together under the umbrella-label of 'flexicurity' - aimed at substituting 'job-based protection' for 'marketbased protection', as they often seem to artificially 'sever' job stability protection from other fundamental employment protection, disregarding the profound links between them, some of which were described above. ${ }^{71}$

It is therefore reductive to see job stability as a mere protection of one's income that can be easily put aside if efficient unemployment benefits and active labour market policy systems were adopted, ${ }^{72}$ replacing salaries and job protection with unemployment benefits and permanent job training. These approaches seem to overlook that, during the employment relationship, people are subject to extensive managerial prerogatives and hierarchical powers of employers, which are enshrined in, and protected by, the law. From a legal point of view, one cannot disregard the fact that employment protection is not only granted with the aim of securing the employee's income but also in order to provide for some countervailing powers to these business prerogatives. ${ }^{73}$ As argued above, dismissal regulation can play a very important role in underpinning the effectiveness of other fundamental and human rights: this role must not be neglected when discussing amendments and reforms of labour market regulations.

\section{CONCLUSION}

In the light of what has been argued in this article, it can be maintained that both the mainstream approach to labour market segmentation and the reforms recently adopted or proposed in several EU Member States to tackle this issue in the context of the economic crisis need profound reconsideration.

${ }^{71}$ See H. Collins, 'Theories of Right as Justifications for Labour Law' in G. Davidov, and B. Langille, The Idea of Labour Law (Oxford: OUP 2011). See also J. Howe (n.57).

${ }^{72}$ And this does not seem to be the case in many European countries, where unemployment benefit systems were materially reduced in recent years: see J. Heyes (n.9).

${ }^{73}$ See O. Kahn-Freund, Labour and the Law (London: Stevens 1972), who chiefly referred to collective labour law. For an analysis of the impact of collective protection at the individual employment contract level see S. Liebman, Individuale e collettivo nel contratto di lavoro (Milano: Giuffrè 1993). 
It has been shown that this mainstream approach, which imputes 'dualism' of labour markets to employment protection, particularly to dismissal regulation, arguably coupling elements of 'insider-outsider' economic theories with the findings of some legal theories concerning the relevant role of the standard employment relationship, is unconvincing. This is because 'insider-outsider' theories do not focus on protection against dismissal, as they generally regard the traditional role of trade unions in the US industrial relations system: these theories, therefore, do not seem applicable to the reality of labour markets in continental Europe. Moreover 'insder-outsider' models are only a part of the economic literature addressing segmentation of labour markets: findings of alternative explanations of segmentation are totally disregarded by the mainstream approach. The same can be said of the findings of legal theories that warn against overestimating the role of law in influencing the economic system; this overestimation is another material flaw of the mainstream approach, which mechanistically links the working conditions of alleged 'insiders' to dismissal protections. Finally, no explanation of the methodologies underpinning the merger of 'insider-outsider' economic theories with the legal theories concerning the standard employment relationship is offered under the mainstream approach. It can then be maintained that this approach gives an oversimplified account of labour market segmentation and of its causes. An alternative explanation of this issue is provided in this article, drawing upon economic and managerial literature concerning 'core/periphery' business models and assessing the potential impact of these models on the marginal workforce.

Coming to the measures adopted or proposed in different EU Member States in response to the economic crisis, it was highlighted that, in general, reforms of employment legislation were not presented as mere deregulations of the labour market; in particular national lawmakers-with the support of the EU Commission-expressly justified these reforms with the need to rebalance protection between allegedly overprotected insiders and underprotected outsiders of labour markets. In practice, however, whilst protection of standard workers was materially loosened in particular by weakening dismissal regulation (for instance by limiting the scope of reinstatement or by materially reducing severance pay), no material improvement in the protection of atypical workers occurred: in some jurisdictions non-standard work was instead further deregulated. Moreover, it was argued that recent legal measures aimed at decentralising collective bargaining systems may discourage trade unions from pursuing solidaristic or inclusive strategies of 
the kind likely to benefit non-standard workers: this aspect has been totally neglected in mainstream approaches to the issue of segmentation.

In the light of this analysis of recent reforms, it can be argued that lawmakers covertly followed a deregulatory path while pushing legal changes through a 'rebalancing-of-protection' rhetoric; the same can be said of proposed reforms - also endorsed by the EU Commission-aimed at introducing a 'single permanent contract' (SPC): in particular, this article has highlighted how, due to the predominantly unskilled character of marginal working activities, introducing the SPC could easily fall short of increasing the job stability of 'outsiders' and would only combat segmentation of the labour market at the expense of standard workers rather than through an enhancement of non-standard workers' protections.

Finally, the article concluded by exploring the links between job stability and workers' fundamental rights; in particular, it was argued that job stability may be pivotal in supporting the effective exercise of these rights and in reducing discrimination at the workplace. There should be further review of SPC proposals and other policy proposals aimed at substituting 'job-based protection' with 'market-based protection', as they tend to disregard the very important role played by dismissal protection in defending fundamental and human rights of workers. 